\title{
Neurocysticercosis: do not miss the eye
}

\author{
Deepanjan Bhattacharya, ${ }^{1,2}$ Asim Ghosh $^{1}$
}

${ }^{1}$ Medical College and Hospital, Kolkata, West Bengal, India ${ }^{2}$ Post Graduate Institute of Medical Education and Research, Chandigarh, India

\section{Correspondence to}

Deepanjan Bhattacharya, b.deepanjan@yahoo.co.in

Accepted 19 October 2018

\section{DESCRIPTION}

A 6-year-old girl presented with new-onset left focal seizures, and was started on valproate. There was no history of fever, headache, visual deficit and neurological examination was completely normal. Neuroimaging revealed ring enhancing lesion in the right parietal lobe. Ocular examination revealed visual acuity of $6 / 6$ in both eyes, with no evidence of uveitis or other abnormality of the anterior segment. Fundus examination revealed hypopigmented area in left retina midway between fovea and optic disc. Optical coherence tomography (OCT) using Spectralis HRA-OCT revealed presence of scolex beneath the retinal pigment epithelium (figure 1A). A Child was started on oral prednisolone and albendazole, and a 28-day course was completed. Repeat OCT revealed resolution of the scolex (figure 1B) and neuroimaging showed disappearance of the ring-enhancing lesion.
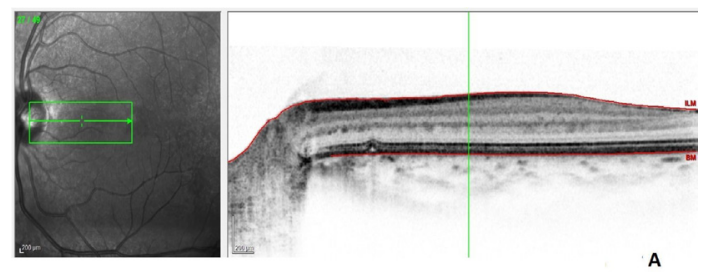

A

(c) BMJ Publishing Group Limited 2018. No commercial re-use. See rights and permissions. Published by BMJ.

To cite: Bhattacharya $D$, Ghosh A. BMJ Case Rep Published Online First: [please include Day Month Year]. doi:10.1136/bcr-2018227869

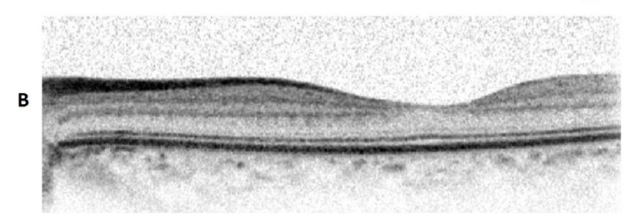

Figure 1 (A) Optical coherence tomography showing scolex beneath the retinal pigment epithelium (B) Optical coherence tomography showing resolution of scolex after completion of therapy.
Cysticercosis is quite a common disease in tropical countries and is often difficult to diagnose. Demonstration of cysticercus by histology or subretinal parasite by funduscopy form absolute criteria for diagnosis of cysticercosis. ${ }^{1}$ Chavala et al reported a 25 -year-old pork handler with intraretinal cysticercosis associated with vision loss, and ocular ultrasound revealing retinal detachment with hypoechoic focus, which responded to antihelmintic therapy. ${ }^{2}$ However, in the index case, there was no visual impairment, and response to therapy was excellent. OCT in suspected cases may be helpful in early detection as well as giving high-resolution images.

\section{Learning points}

- Ocular examination is of paramount importance in neurocysticercosis.

- Optical coherence tomography can diagnose lesions better with better resolution.

Contributors DB: patient management, literature review and preparation of the initial draft of the manuscript. AG: clinician-incharge, critical review of the manuscript for important intellectual content and final approval of the version to be published.

Funding The authors have not declared a specific grant for this research from any funding agency in the public, commercial or not-for-profit sectors.
Dernesticercosis. I Neurol Sci 2017:372:202-10.

Chavala SH, Melamud A, Williamson JF. Intraretinal cysticercosis. Lancet 2015;385:799.
Copyright 2018 BMJ Publishing Group. All rights reserved. For permission to reuse any of this content visit http://group.bmj.com/group/rights-licensing/permissions.

BMJ Case Report Fellows may re-use this article for personal use and teaching without any further permission.

Become a Fellow of BMJ Case Reports today and you can:

- Submit as many cases as you like

- Enjoy fast sympathetic peer review and rapid publication of accepted articles

- Access all the published articles

- Re-use any of the published material for personal use and teaching without further permission

For information on Institutional Fellowships contact consortiasales@bmjgroup.com

Visit casereports.bmj.com for more articles like this and to become a Fellow 